\title{
Monitoring Particulate Matter Air Pollution in Urban Centers: New Insights from Douala, Cameroon
}

\author{
By Aguh Akeh Nug ${ }^{*}$, Cheo Emmanuel Suh ${ }^{ \pm}$, Johan Boman ${ }^{*}$ \& \\ Godwin Sendze Yinda ${ }^{+}$
}

\begin{abstract}
Air quality progressively deteriorates as urbanization, motorization and economic activities increase. Aerosol particles smaller than 2.5 $\mu m\left(P M_{2.5}\right), a$ widespread form of pollution is an emergent threat to human health, the environment, quality of life, and the world's climate. The composition of these particles is an important aspect of interest not only related to possible health and environmental effects of the elemental content but the elemental determination which also adds valuable information for source apportionment. This study investigates and evaluates the level of $P M_{2.5}$ in Douala, Cameroon. Particles were collected using a cyclone that separates the PM 2.5 from the air stream and impacts them on polycarbonate filters which were changed every 24-hour sampling period. Samples were analyzed for particulate mass concentration, black carbon (BC) and trace elements. Trace element analysis was done by EDXRF (energy dispersive $x$-ray fluorescence spectroscopy). $C l$, $\mathrm{K}, \mathrm{Ca}, \mathrm{Ti}, \mathrm{Mn}, \mathrm{Fe}, \mathrm{Ni}, \mathrm{Cu}, \mathrm{Zn}, \mathrm{Br}, \mathrm{Sr}$, and $\mathrm{Pb}$ were identified and quantified for samples. Local meteorology was used to study variations in $P M_{2.5}$ mass concentrations. Possible sources for the pollutants were also investigated. The mean particle mass concentration was $252 \pm 130 \mu \mathrm{g} / \mathrm{m}^{3}$ while BC attained a maximum of $6.993 \mu \mathrm{g} / \mathrm{m}^{3}$. The influence of leaded gasoline was inferred while combustion and road traffic were identified as the major anthropogenic sources. Trends in meteorological parameters were influenced by thunderstorms. Sea spray was identified as another major contributor to aerosol PM. This study highlights high pollution levels in Douala.
\end{abstract}

Keywords: $P M_{2.5}$, air quality, aerosol, mass concentration, source identification

\section{Introduction}

With the recent upsurge in globalization and industrialization coupled with increasing pressures of global climate change, deforestation and shifts in land use pattern, air pollution is emerging as one of the major factors influencing human health, agriculture and natural ecosystems (Agrawal et al. 2003, Kuan et al. 2017, Sánchez de la Campa et al. 2018). Air quality is of particular concern due to the degradation of human health attributed to it. Air borne particles that play pivotal roles in human health and atmospheric processes such as fog and cloud formation, visibility, solar radiation and precipitation, acidification of clouds, rain and fog, and climate change as a whole are of particular interest (Goldoni et al. 2006,

\footnotetext{
*Lecturer, The University of Bamenda, Cameroon.

${ }^{ \pm}$Professor and Deputy Vice-Chancellor, The University of Bamenda, Cameroon.

*Professor, University of Gothenburg, Sweden.

${ }^{+}$Senior Lecturer and Vice Dean, The University of Buea, Cameroon.
} 
Dawson et al. 2007, Kawata et al. 2007, Donaldson et al. 2009, Kelly and Fussell 2011, Tiwari et al. 2012, Amodio et al. 2013).

The health burden due to particulate matter (PM) air pollution $\left(\mathrm{PM}_{10}\right.$ and $\mathrm{PM}_{2.5}$ ) is one of the biggest environmental health concerns globally (Kuan et al. 2017, Loxham and Nieuwenhuijsen 2019). According to Loxham and Nieuwenhuijsen (2019) and Ariundelger et al. (2020), exposure to ambient airborne PM is a major risk factor for mortality and morbidity, associated with asthma, lung cancer, heart disease, myocardial infarction, and stroke, and more recently type 2 diabetes, dementia and loss of cognitive function especially in urban centers where urbanization, motorization, and rapid economic growth rapidly deteriorate the quality of the air (Boman et al. 2009a, Bell et al. 2009, Kuan et al. 2017, Cao et al. 2018). The size of particles affects their ability to penetrate the human respiratory system causing adverse health effects (Schwarze et al. 2006, Seinfield and Pandis 2006, Kaonga and Ebenso 2011). Exposure to fine particles especially $\mathrm{PM}_{2.5}$ which are aerosol particles with aerodynamic diameter $\leq 2.5 \mu \mathrm{m}$ can cause short and long term effects such as decreased lung function, alterations in tissue and lung structure, increased respiratory symptoms, alterations in the respiratory tract and even premature death (Tsai et al. 2003, Katsouyanni et al. 2009, Kuan et al. 2017). Increased toxicity and PM carcinogenicity have been strongly associated with the elemental composition of $\mathrm{PM}$ and the presence of polycyclic aromatic hydrocarbons (PAHs) in the finer particles. New evidence shows that long-term exposure to air pollution not only affects outcomes such as premature deaths but also contributes to the development and progression of subclinical and clinical disease such as serious cardiopulmonary defects, as well as some unexpected responses in the liver and brain (WHO 2007).

More attention is required for "Heavy metals", usually referred to as metallic chemical elements having a relatively high density and toxic or poisonous at low concentrations $(\mathrm{Hg}, \mathrm{Cd}, \mathrm{As}, \mathrm{Cr}, \mathrm{Ni}$ and $\mathrm{Pb})$. In addition, trace metals are proven to be useful tracers and are extensively used to identify sources of emissions to be targeted by the emission reduction policies (Gotschi et al. 2005, Querol et al. 2006, 2007, Viana et al. 2007, Jeong et al. 2008).

According to WHO (2005), Forster (2007) and Tai et al. (2012), climatic conditions have direct effects on the concentration, dispersion and life time of aerosol particles in the atmosphere. The dynamics of the atmosphere and the meteorological conditions play a vital role in governing the fate of air pollutants. Lecoeur et al. (2012) states that concentrations of PM are strongly dependent on meteorological conditions of which temperature, wind speed, humidity, rain rate and mixing height are the variables that impact PM concentrations the most. In this study, the relationship between ambient PM concentration and meteorological variables, such as temperature, rainfall, wind speed and direction and relative humidity is statistically analyzed.

In Cameroon, Douala is of particular interest for air pollution studies because of its dense population coupled with intense industrial and commercial activities (Kemajou et al. 2007). However, there has been limited air pollution research in this city. 
With focus on $\mathrm{PM}_{2.5}$, spatial analysis and temporal variations of air pollution in areas of different development typology in Douala, the economic capital of Cameroon was studied. Detailed measurements of air pollution $\left(\mathrm{PM}_{2.5}\right)$ were carried out at street sites in 2 industrial zones ( 1 semi industrial interspersed with residential and commercial neighborhoods, and 1 absolute industrial zone) and a residential neighborhood all of which were centrally located and paved neighborhoods.

\section{Literature Review}

Ambient PM is a complex mixture of solid and liquid particles suspended in air (Seinfeld and Pandis 2006, Adams et al. 2015). The size, chemical composition, and other physical and biological properties of particles vary with location and time. This variability in pollutant levels derives from differences in pollutant sources, and the characteristic weather parameters of the area (Pinto Miranda Garcia et al. 2018). The sources may be natural, such as forest fires volcanoes, dust storms, forest and grassland fires, living vegetation and sea spray (Omidvarborna et al. 2015, Adams et al. 2015, Loxham and Nieuwenhuijsen 2019), or the result of human activities, such as the burning of fossil fuels in vehicles (Omidvarborna et al. 2015), stubble burning, manufacturing and power plants (Adams et al. 2015), wet cooling towers in cooling systems and various industrial processes, also generate significant amounts of particulates. Coal combustion in developing countries is the primary method for heating homes and supplying energy thus a significant source of PM (Omidvarborna et al. 2015). Salt spray over the oceans is the overwhelmingly most common form of particulate in the atmosphere. As stated by Webb and Pierre (2018) and Wang et al. (2018), anthropogenic aerosols currently account for between $10 \%$ and $60 \%$ of the total mass of global aerosols in the atmosphere.

According to Seinfeld and Pandis (2006), Brook et al. (2010), Heal et al. (2012), Adams et al. (2015) and Manisalidis et al. (2020), air pollutants may either be emitted directly into the atmosphere (primary pollutants) or formed within the atmosphere itself through chemical reactions and physical processes (secondary pollutants). Heal et al. (2012), further classifies them as inhalable, thoracic and respirable dust fractions depending on the depth of penetration of the particle into the respiratory system. The inhalable dust fraction with a size threshold of about $50 \mu \mathrm{m}$ can be captured by inhalation in the nasal cavity (easily filtered by cilia or mucus). The dust fraction reaching all the way to the lungs (lower respiratory tract) is the thoracic dust fraction. These are particles $\leq 10$ but $>2.5 \mu \mathrm{m}$ (Boman et al. 2010, Fortoul et al. 2012, Manisalidis et al. 2020), and the fine dust that can penetrate even further into the bronchioles and alveoli (gas exchange region) is known as the respirable dust fraction. These particles are not ejected by breathing out, coughing, or expulsion by mucus, and approximate a particle size threshold of

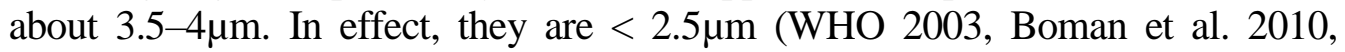
Fortoul et al. 2012, Heal et al. 2012), and are capable of reaching the gas exchange surfaces of the alveoli (Heal et al. 2012). 
It should be noted that ambient PM levels in any particular location are also affected by local ambient mixtures of gaseous pollutants, meteorology, geography, and seasonal patterns (Adams et al. 2015, Pinto Miranda Garcia et al. 2018).

\section{Meteorological Implications of Particulate Matter}

According to Tai et al. (2012), Lecoeur et al. (2012) and Li et al. (2017), the fate of air pollutants is influenced by the movements and characteristics of the air mass into which they are emitted. The measurements of wind speed and direction, temperature, humidity, rainfall and solar radiation are important parameters used in the study of air quality and can assist in furthering understanding of the chemical reactions that occur in the atmosphere (Lecoeur et al. 2012, Wei et al. 2012, Pinto Miranda Garcia et al. 2018).

As stated by Tai et al. (2010) and Li et al. (2017), $\mathrm{PM}_{2.5}$ concentrations depend on meteorological conditions, suggesting that climate change could have significant effects on $\mathrm{PM}_{2.5}$ air quality and vice versa. PM is comprised of many different species, and meteorology can have complex effects on total PM concentrations due to its impacts on individual species (Dawson et al. 2007, Zhou et al. 2020). Aerosol $\mathrm{SO}_{4}{ }^{2-}$ concentrations depend on the temperature-dependent oxidation of $\mathrm{SO}_{2}$ in both the gas and aqueous phases, and sunlight intensity (Seinfeld and Pandis 2006, Dawson et al. 2007, Zhou et al. 2020). On the other hand, concentrations of semi-volatile $\mathrm{NO}_{3}{ }^{-}$and organic aerosols are temperature and relative humidity dependent; they can also vary with the amount of oxidants present, which is linked to photolysis rates and, therefore, cloud cover (Dawson et al. 2007). Tai et al. (2010), Dawson et al. (2007) and Tsigaridis and Kanakidou (2007) report that $\mathrm{SO}_{4}{ }^{2-}$ concentrations are expected to increase with increasing temperature due to faster $\mathrm{SO}_{2}$ oxidation, but semi-volatile components such as $\mathrm{NO}_{3}{ }^{-}$and organics are expected to decrease as they shift from the particle phase to the gas phase at higher temperature.

Higher relative humidity $(\mathrm{RH})$ promotes the formation of ammonium nitrate, but an increase in precipitation causes a decrease in all $\mathrm{PM}_{2.5}$ components through scavenging and since all species have wet deposition as a sink, precipitation is expected to have a significant effect on aerosol concentrations (Dawson et al. 2007). During a study by Dawson et al. (2007), it was observed that the changes in $\mathrm{PM}_{2.5}$ resulted even in areas with little or no base-case precipitation indicating that changes in precipitation in upwind areas affected $\mathrm{PM}_{2.5}$ concentrations in downwind areas. Seinfeld and Pandis (2006) conclude that changes in absolute humidity have the largest effects on concentrations of ammonium nitrate aerosol with concentrations increasing with increased absolute humidity and that increases in humidity shift the equilibrium of the ammonia-nitric acid system toward the aerosol phase, resulting in higher concentrations of ammonium nitrate aerosol.

Finally, mixing and dilution influence PM concentrations, so wind speed and mixing height are expected to have an impact as well. According to Tai et al. (2010), if the air is calm and pollutants cannot disperse then the concentration of these pollutants will build up. Conversely, if a strong, turbulent wind is blowing any pollution generated will be rapidly dispersed into the atmosphere resulting in 
lower pollutant concentrations in the air. Wind speed changes affect all species that comprise $\mathrm{PM}_{2.5}$, with increases in wind speed generally leading to decreases in $\mathrm{PM}_{2.5}$ concentrations, and decreases in wind speed generally leading to increases in $\mathrm{PM}_{2.5}$ (Dawson et al. 2007, Ya-Gao et al. 2019). According to Brook et al. (2010), increases in wind speed leads to changes in advection and transport resulting in decreases in $\mathrm{PM}_{2.5}$ concentrations.

\section{Objectives}

This study seeks to investigate and evaluate the level of PM in the industrial town of Douala in Cameroon. The objectives of the study were to analyse and quantify $\mathrm{PM}_{2.5}$ in terms of mass and mass concentration and the elemental composition of the PM found in Douala. The study also focused on determining the influence of meteorological parameters on $\mathrm{PM}_{2.5}$ concentration in Douala, embarked on apportioning sources to the different PM components that would be identified, and analyzing the variation of fine particles with meteorological parameters, and determine the sources of the $\mathrm{PM}_{2.5}$ in the area.

\section{Methodology}

\section{Sample Collection}

Sampling was done using an electrically powered cyclonic sampler (Casella Group Ltd) capable of collecting PM in $\mathrm{PM}_{2.5-10}$ size fractions. The cyclone separates the $\mathrm{PM}_{2.5}$ particles from the air stream and impacts them on polycarbonate filters. Operating at a constant volumetric flow rate of $3 \mathrm{~L} / \mathrm{min}, \mathrm{PM}_{2.5}$ particles were collected for a period of 1 month. The flow through the cyclone was kept constant by a critical orifice (accuracy of $\pm 15 \%$ ) to maintain a particle cut off diameter of $2.5 \mu \mathrm{m}$. Sample collection was done at a daily temporal resolution and temporal coverage from 30/10/2012-29/11/2012. The set up was mounted at each location for 9 sampling days after which it was mounted at the next location. Filters were changed after every $24 \mathrm{~h}$ sampling period. Since the same setup was used during the whole campaign the different samples can be compared with each other without being influenced by possible differences in sampling flow (Boman et al. 2010)

Purposefully, samples were collected at 3 sites in the industrial town of Douala (Figure 1); Site 1, the Bonaberi industrial zone (longitude $09^{\circ} 74$ " East and latitude $04^{\circ} 09^{\prime \prime}$ North), Site 2 , the Bassa industrial zone (longitude $09^{\circ} 68^{\prime \prime}$ East and latitude $04^{\circ} 07^{\prime \prime}$ North) and Site 3 , the Bonamoussadi residential zone (longitude $09^{\circ} 75^{\prime}$ "East and latitude $04^{\circ} 04^{\prime \prime}$ North). At site 1 , the sampler was placed at a height of $8.5 \mathrm{~m}$ above ground with the intake nozzle placed $1.5 \mathrm{~m}$ above the platform on which the sampler was placed. The nozzle was placed such that airflow was unobstructed (at all sites) about $200 \mathrm{~m}$ away from the industrial area and $50 \mathrm{~m}$ away from the road. The Bassa site saw similar sampling conditions. The sampler was placed facing the industrial zone but away from the road $100 \mathrm{~m}$ away. 
It was placed $8.0 \mathrm{~m}$ above ground and $80 \mathrm{~m}$ away from the railway. At site 3 the sampler was placed on the flat roof $5 \mathrm{~m}$ above ground with the nozzle position $2 \mathrm{~m}$ above the roof and $100 \mathrm{~m}$ away from the roadside. The sampler was placed such that air flow was unobstructed. Effective sampling time was \pm 24 hours.

Particle collection was done on $25 \mathrm{~mm}$ diameter Teflon filters with a pore size of $0.4 \mu \mathrm{m}$. The polycarbonate filters were initially preconditioned at $45 \%$ relative humidity and $20^{\circ} \mathrm{C}$ (equilibrium conditions intended to minimize the liquid water associated with soluble compounds and to minimize the loss of volatile species as stated by Chow and Watson (1998). These conditions ensure that particle growth due to accumulation is minimized) before they were weighed and placed in Petri dishes. After sampling, the filters were again placed and stored in the same dishes. An OHAUS Adventurer Pro electronic analytical microbalance with a sensitivity of $0.0001 \mathrm{mg}$ was used for gravimetric determination of the sampled particle mass. The set up was mounted at each location for 9 sampling days. Since the same setup was used during the whole campaign the different samples can be compared with each other without being influenced by possible differences in sampling flow.

Figure 1. Map of Study Area showing Sampling Sites in Douala

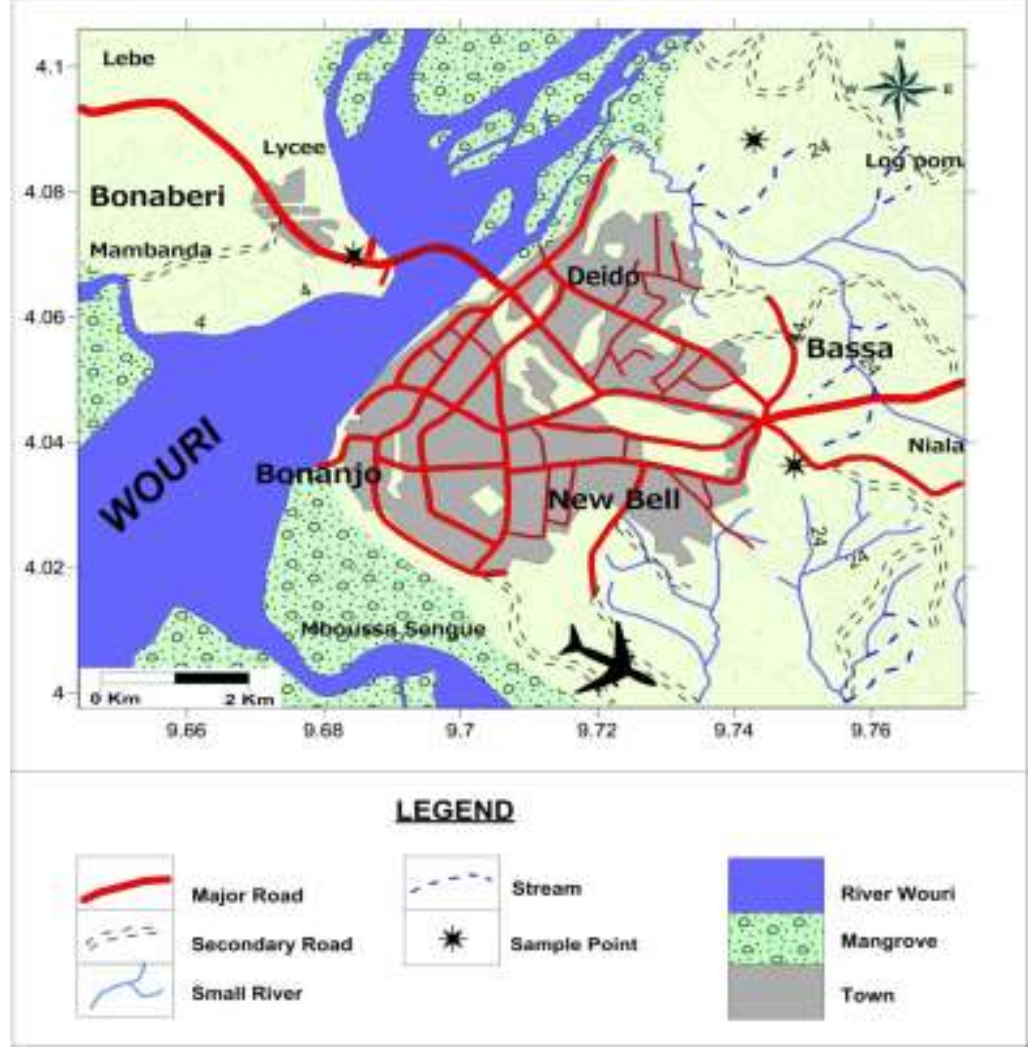

Source: Fieldwork 2012.

The climate of this region is uniform and is described as a particular equatorial type marked by a lengthy rainy season (at least nine months), abundant rainfall (about $4000 \mathrm{~mm}$ per annum), high and stable average annual temperatures $\left(26.7^{\circ} \mathrm{C}\right)$ (Siegfried et al. 2009). The mean of the minimum temperature calculated in Douala for 30 years is $22.6^{\circ} \mathrm{C}$ in July and the mean of the maximum temperature 
is $32.3^{\circ} \mathrm{C}$ in February. The relative air humidity remains high throughout the year with a mean value of $82.6 \%$; the lowest value being around $60 \%$ in February and the highest is $100 \%$ in the rainy season (Din et al. 2008). Rainfall is bimodal, peaking at July and August with minimal rainfall in January and February and varies from 78.0-1215.0 mm/month and an average rainfall of $2900 \mathrm{~mm} / \mathrm{year}$ (Djuikom et al. 2011, Fonge et al. 2011).

\section{Sample Analysis}

The samples were analyzed for PM mass concentration, elemental composition and black carbon. A principal component analysis (PCA) was conducted to apportion PM sources.

Gravimetric analysis was performed to determine the mass concentration of the sample aerosol.

The total volume of air sampled was determined from the volumetric flow rate of $3 \mathrm{~L} / \mathrm{min}$. The concentration of $\mathrm{PM}_{2.5}$ in the ambient air is computed as total mass of collected particles divided by the volume of air sampled in actual conditions. The concentrations are expressed in micrograms per actual cubic meter $\left(\mu \mathrm{g} / \mathrm{m}^{3}\right)$. The equation governing the gravimetric analysis is given below:

Where,

$$
C_{P M}=\frac{M}{V}
$$

$\mathrm{C}_{\mathrm{PM}}=$ PM Mass Concentration

$\mathrm{M} \quad=$ Net mass of the particulate matter collected on the sample filter

$\mathrm{V}=$ The volume of air sampled

Samples obtained were analyzed for elemental composition by Energy Dispersive X-Ray Fluorescence (EDXRF) spectrometry (Van Grieken and Markowicz 1993). The spectrometer based on a three-axial geometry consisted of a Siemens Mo-anode X-ray tube with a Mo secondary target that facilitated a good signal to background ratio giving low detection limits (Table 2), and a Kevex Si (Li) detector. According to Boman et al. (2009a) and Gatari et al. (2006), the spectrometer was operated at $50 \mathrm{kV}$ and $25 \mathrm{~mA}$ and the samples were analyzed for 1000s. To ensure and verify the validity of the results obtained, a certified reference material (\#2783, Air Particulate on filter media, NIST, USA) was used. For spectrometer calibration, thin film standards with specified uncertainty of 5\% in the elemental concentration were used (Micromatter Inc., Seattle, WA, USA). By repeatedly analysing two aerosol filter samples the mean analytical precision of the spectrometer was determined to be 5\% (Moln'ar et al. 2006). Sample elemental spectra were obtained and evaluated by a quantitative $\mathrm{x}$-ray analysis system (QXAS) software provided by the International Atomic Energy Agency (IAEA) laboratories, Seibersdorf, Austria. Atmospheric concentrations and detection limits (DLs) were determined and several of the elements below detection limits were excluded from analysis. 
BC concentrations were determined by a Black Smoke Detector Model FH 621-N (ESM Emberline, Erlangen, Germany). This instrument is a reflectmeter that has light emitting diodes (LEDs) and photosensors enclosed in a completely black casing. The LEDs (red light emitting diodes for this case) illuminate the sample with optimized light that is tuned at a wavelength of $0.6 \mu \mathrm{m}$. The reflected light intensity is sensed by the photosensors that translate the light intensity to electrical current. The voltage reading is related to the level of sample blackness and subsequently recalculated into BC concentrations. For QC/QA (quality control and Quality assurance) measures, appropriate filter substrate was selected and tested for sampling effectiveness prior to field sampling. The filters were preconditioned to removed contaminants and ensure quality of air sampled. Laboratory accredited program was used to assure the quality. The sensors in the instrument used were also calibrated for purposes of QC/QA.

\section{Principal Component Analysis}

Factor analysis with Principal Components as extraction method known as Principal Component Analysis (PCA) in air quality studies is widely used to provide information on PM or gaseous pollutant sources (Querol et al. 2001, Amodio et al. 2010). The PCA technique identifies components that explain the common variation pattern of the included variables (elements, and BC) based on the principle that elements with similar concentration patterns most likely originate from a common source. The components are identified by the PCA, and possible sources of the components ascribed. Values $<0.3$ have low loading, those between 0.3 and 0.6 are considered to have moderate loadings, those with 0.8 are said to be moderately high loadings and values $>0.8$ are considered as high loadings (Boman et al. 2009a).

\section{Meteorological Conditions}

Since $\mathrm{PM}_{2.5}$ concentrations are strongly dependent on meteorological conditions, it is important to investigate the relationships between $\mathrm{PM}_{2.5}$ and meteorological parameters (Lecoeur et al. 2012). The meteorological information during the measurement campaign was obtained from the Douala Meteorological centre which records such data for the entire city. The website "http:/wunderg round.com" was also valuable in getting certain daily variations for some climate parameters. 


\section{Results and Discussion}

\section{Mass and Mass Concentration}

The mean mass and mass concentration of PM collected from the 3 sites is as shown in Table 1.

Table 1. Mass and Mass Concentration for All Sampling Sites

\begin{tabular}{|c|c|c|c|c|c|c|c|c|}
\hline Sample Code & $\operatorname{Mass}(\mathrm{g})$ & $\begin{array}{c}\text { Mass } \\
\text { Conc } \\
\left(\mu \mathrm{g} / \mathrm{m}^{3}\right)\end{array}$ & $\begin{array}{c}\text { Sample } \\
\text { Code }\end{array}$ & $\operatorname{Mass}(\mathrm{g})$ & $\begin{array}{c}\text { Mass } \\
\text { Conc } \\
\left(\mu \mathrm{gg} / \mathbf{m}^{3}\right)\end{array}$ & $\begin{array}{c}\text { Sample } \\
\text { Code }\end{array}$ & $\begin{array}{c}\text { Mass } \\
(\mathrm{g})\end{array}$ & $\begin{array}{c}\text { Mass } \\
\text { Conc } \\
\left(\mu \mathrm{g} / \mathrm{m}^{3}\right)\end{array}$ \\
\hline Bonamoussadi 1 & 0.0010 & 224 & Bonaberi 1 & 0.0005 & 116 & Bassa 1 & 0.0010 & 236 \\
\hline Bonamoussadi 2 & 0.0003 & 77.2 & Bonaberi 2 & 0.0003 & 78.4 & Bassa 2 & 0.0020 & 463 \\
\hline Bonamoussadi 3 & 0.0010 & 224 & Bonaberi 3 & 0.0015 & 347 & Bassai 3 & 0.0010 & 232 \\
\hline Bonamoussadi 4 & 0.0006 & 147 & Bonaberi 4 & 0.0025 & 579 & Bassa 4 & 0.0013 & 307 \\
\hline Bonamoussadi 5 & 0.0010 & 232 & Bonaberi 5 & 0.0012 & 270 & Bassa 6 & 0.0003 & 77 \\
\hline Bonamoussadi 6 & 0.0014 & 316 & Bonaberi 7 & 0.0000 & 0 & Bassa 7 & 0.0013 & 309 \\
\hline Bonamoussadi 7 & 0.0010 & 224 & Bonaberi 8 & 0.0017 & 386 & Bassa 8 & 0.0010 & 232 \\
\hline Bonamoussadi 8 & 0.0010 & 232 & Bonaberi 9 & 0.0018 & 424 & Bassa 9 & 0.0013 & 307 \\
\hline Mean & 0.0009 & 209 & Mean & 0.0012 & 275 & Mean & 0.00115 & 271 \\
\hline Standard Dev. & 0.000327 & 70.2 & $\begin{array}{c}\text { Standard } \\
\text { Dev. }\end{array}$ & 0.000856 & 197 & $\begin{array}{c}\text { Standard } \\
\text { Dev. }\end{array}$ & 0.000475 & 109 \\
\hline Range & $\begin{array}{c}0.0003- \\
0.0014 \\
\end{array}$ & $\begin{array}{c}77.2- \\
316 \\
\end{array}$ & Range & $0-0.0025$ & $0-579$ & Range & $\begin{array}{c}0.0003- \\
0.002 \\
\end{array}$ & $77-463$ \\
\hline Median & 0.001 & 224 & Median & 0.00135 & 309 & Median & 0.00115 & 273 \\
\hline
\end{tabular}

Source: Fieldwork 2012.

The cumulative mean concentration for all sites is $252 \pm 130 \mu \mathrm{g} / \mathrm{m}^{3}$ which is relatively higher than the WHO Guideline of $25 \mu \mathrm{g} / \mathrm{m}^{3}$ for $\mathrm{PM}_{2.5}$ (24-hour mean), as stated by Heal et al. (2012). The daily variation in particle mass concentration of $\mathrm{PM}_{2.5}$ in Douala is clearly shown in Figure 2.

Figure 2. Daily Variations in Particle Mass Concentration of $P_{2.5}$ in Douala

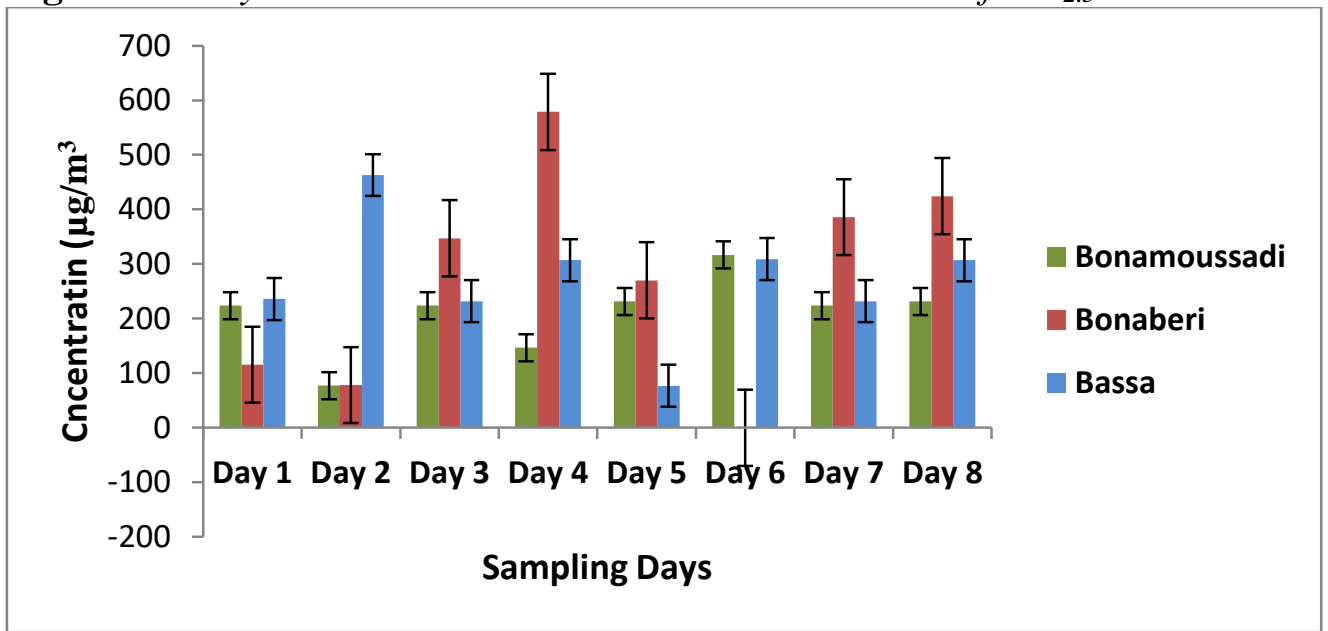

Source: Fieldwork 2012. 
The huge population of the city, the wide range of commercial and industrial activities, variety of old and new, maintained and poorly maintained vehicles, large scale two wheel activities, and the dependence of the population on biomass significantly contribute to the high value of $\mathrm{PM}_{2.5}$ mass concentration. According to UN (2018), most vehicles imported into the country range are used or old vehicles (emit a disproportionate amount of pollutants) which between 6-9 years. Nonetheless, JV (2013) puts forward that some of these second hand vehicles are as old as 20 years, although the 2011 financial law of the country permits only the entry of cars of maximum 7years of age. Mercedes Benz MB 100 D that was first manufactured in 1981 is still being imported into the county. Named "cargo", this wagon carries up to 25 persons within the Douala city. Similarly, vehicles on Cameroonian roads such as taxis date between 1980 and 1990, states the paper.

Open burning and the high dependence on fuel wood and charcoal for domestic and commercial purposes significantly contributes the high BC concentrations for all sampling sites.

\section{Elemental Analysis}

EDXRF was run for 22 elements, and a total of 12 elements were identified (above detection limits as shown in Table 2), and quantified in most of the samples; $\mathrm{Cl}, \mathrm{K}, \mathrm{Ca}, \mathrm{Ti}, \mathrm{Mn}, \mathrm{Fe}, \mathrm{Ni}, \mathrm{Cu}, \mathrm{Zn}, \mathrm{Br}, \mathrm{Sr}$, and $\mathrm{Pb}$ (Table 2).

Sample collection was done at a daily temporal resolution and temporal coverage from 30/10/2012-29/11/2012. The set up was mounted at each location for 9 sampling days after which it was mounted at the next location. Filters were changed after every $24 \mathrm{~h}$ sampling period implying that after every 24 hours the filters were changed. Since the same setup was used during the whole campaign the different samples can be compared with each other without being influenced by possible differences in sampling flow.

Table 2. Detection Limits (DL) in $\mu \mathrm{g} / \mathrm{m}^{3}$ for the Analysed Elements

\begin{tabular}{|c|c|c|c|c|c|c|c|c|c|c|c|c|}
\hline Elt & $\mathrm{Cl}$ & $\mathbf{K}$ & $\mathbf{C a}$ & $\mathbf{T i}$ & Mn & $\mathbf{F e}$ & $\mathbf{N i}$ & $\mathbf{C u}$ & $\mathbf{Z n}$ & $\mathrm{Br}$ & $\mathbf{S r}$ & $\mathbf{P b}$ \\
\hline DL & $\stackrel{?}{3}$ & 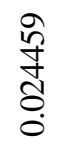 & 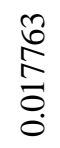 & 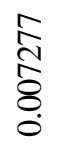 & 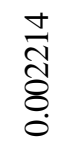 & $\begin{array}{l}\text { ठิे } \\
\text { ઠे } \\
\text { ठ. }\end{array}$ & రి & $\frac{2}{8}$ & $\begin{array}{l}\stackrel{+}{N} \\
\frac{0}{8} \\
0\end{array}$ & $\overline{\bar{\sigma}}$ & $\overline{\bar{\sigma}}$ & $\begin{array}{l}\stackrel{\mathrm{J}}{0} \\
\text { } \\
0\end{array}$ \\
\hline
\end{tabular}

NB: Three axial geometry with Mo secondary target. X-ray tube operated with $50 \mathrm{kV}$ and $25 \mathrm{~mA}$. Lifetime of 1000s. A collection time of $24 \mathrm{~h}$.

Source: Fieldwork 2012.

Full campaign concentration means with standard deviations in $\mu \mathrm{g} / \mathrm{m}^{3}$ for the analysed elements and the $\mathrm{PM}_{2.5}$ mass concentrations at the three sites including $\mathrm{BC}$ concentrations in $\mu \mathrm{g} / \mathrm{m}^{3}$ are given in Table 3. Reported elemental concentrations are those above DL and blank filter concentrations while $\mathrm{N}$ is the number of samples with concentrations above DL. DL for analysed elements ranged from $0.0011 \mu \mathrm{g} / \mathrm{m}^{3}$ for $\mathrm{Br}$ and $\mathrm{Sr}$ to $0.12 \mu \mathrm{g} / \mathrm{m}^{3}$ for $\mathrm{Cl}$ as shown in Table 2 while Figure 3 shows how the elemental concentration varied at different sites. 
Table 3. Average Elemental Concentrations for the Entire City

\begin{tabular}{|l|c|c|c|}
\hline Parameter & Range & Average $\left(\boldsymbol{\mu g} / \mathbf{m}^{\mathbf{3}}\right)$ & $\mathbf{N}(\mathbf{M a x}=\mathbf{2 4})$ \\
\hline $\begin{array}{l}\text { Particle mass } \\
\text { concentration } \\
\left(\mu \mathrm{g} / \mathrm{m}^{3}\right)\end{array}$ & $0-578.7$ & $251.4 \pm 133.7$ & 24 \\
\hline $\mathrm{Black}$ Carbon & $0-7.0$ & $1.9 \pm 1.815$ & 21 \\
\hline $\mathrm{Cl}$ & $0.131-0.760$ & $0.347 \pm 0.189$ & 9 \\
\hline $\mathrm{K}$ & $0.048-0.507$ & $0.164 \pm 0.103$ & 19 \\
\hline $\mathrm{Ca}$ & $0.027-0.810$ & $0.190 \pm 0.195$ & 23 \\
\hline $\mathrm{Ti}$ & $0.008-0.085$ & $0.029 \pm 0.020$ & 18 \\
\hline $\mathrm{Mn}$ & $0.003-0.126$ & $0.017 \pm 0.033$ & 13 \\
\hline $\mathrm{Fe}$ & $0.035-0.917$ & $0.248 \pm 0.216$ & 24 \\
\hline $\mathrm{Ni}$ & $0.003-0.009$ & $0.005 \pm 0.002$ & 4 \\
\hline $\mathrm{Cu}$ & $0.002-0.013$ & $0.005 \pm 0.003$ & 17 \\
\hline $\mathrm{Zn}$ & $0.004-1.777$ & $0.296 \pm 0.469$ & 24 \\
\hline $\mathrm{Br}$ & $0.017-0.040$ & $0.022 \pm 0.005$ & 24 \\
\hline $\mathrm{Sr}$ & $0.001-0.022$ & $0.004 \pm 0.005$ & 15 \\
\hline $\mathrm{Pb}$ & $0.007-2.075$ & $0.292 \pm 0.48$ & 24 \\
\hline $\mathrm{Sb}$ & & & \\
\hline
\end{tabular}

Source: Fieldwork 2012.

Figure 3. Variation of Elemental Concentration at Different Sites

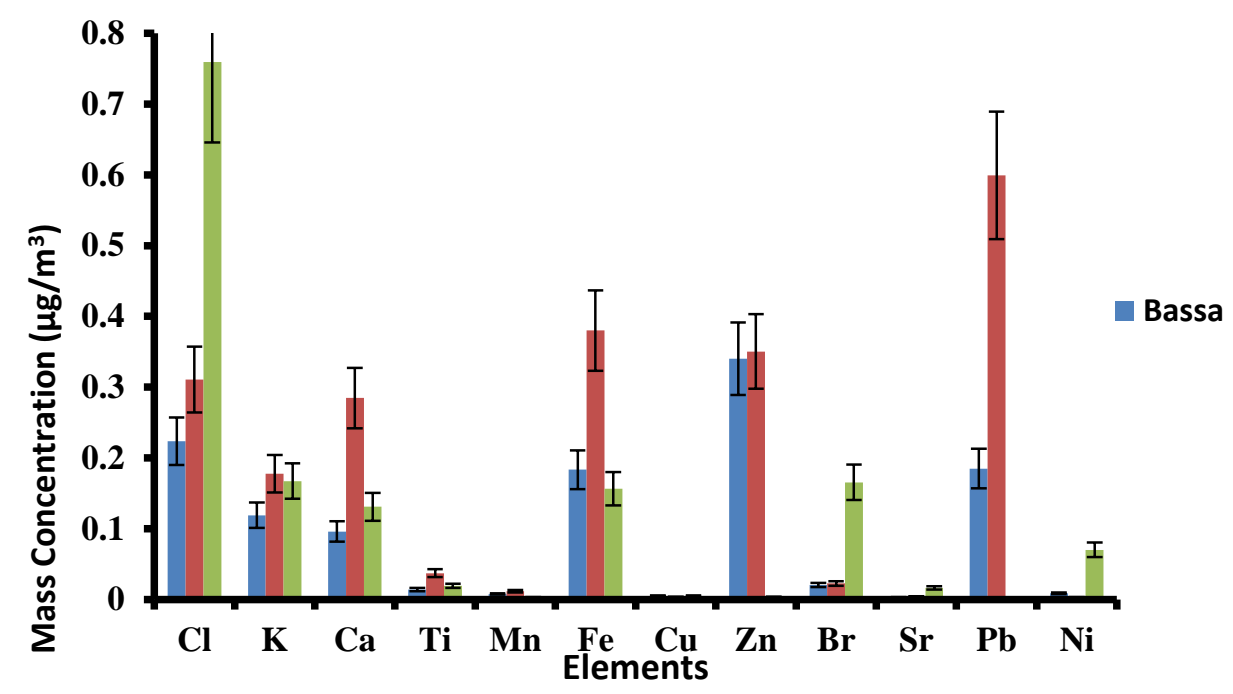

For Bonaberi, $\mathrm{Ca}, \mathrm{Fe}, \mathrm{Zn}, \mathrm{Br}$ and $\mathrm{Pb}$ were present in all samples while for Bassa only $\mathrm{Fe}, \mathrm{Zn}, \mathrm{Br}$ and $\mathrm{Pb}$ were identified in all samples. $\mathrm{Cl}$ and $\mathrm{Ni}$ have the lowest frequencies of occurrence with $\mathrm{Cl}$ appearing only once in Bonamoussadi, $\mathrm{Ni}$ appearing twice in Bonamoussadi, once in Bonaberi and Bassa with the highest concentration recorded in Bassa.

All concentrations but for $\mathrm{Fe}, \mathrm{Zn}$ and $\mathrm{Pb}$ have concentrations $<0.3 \mu \mathrm{g} / \mathrm{m}^{3}$ for Bonaberi. But for $\mathrm{Cl}$, all other elements have concentrations $<0.3 \mu \mathrm{g} / \mathrm{m}^{3}$ for Bonamoussadi and Bassa. Ca presents relatively high concentrations in Bonaberi than for the other zones most probably due to the presence of the cement industry which is present in Bonaberi and absent in the other zones. 
While the concentration of $\mathrm{Br}$ is relatively low for the other zones, Bonamoussadi presents a higher $\mathrm{Br}$ concentration. The high $\mathrm{Br}$ concentration could be explained by a high input of particles from biomass burning, since $\mathrm{Br}$ can be tracer element for pyrogenic biomass burning.

The possible contribution of $\mathrm{Br}$ from sea spray or some combustion source especially vehicle exhaust cannot be excluded (Boman et al. 2009b). Apart from $\mathrm{Cl}, \mathrm{K}$ and $\mathrm{Ca}$ which are higher in Bonamoussadi than in Bassa, Bonamoussadi generally has lowest concentrations. It can then be concluded that Bonaberi has highest elemental concentrations followed by Bassa then by Bonamoussadi. The industrial zones therefore contain more $\mathrm{PM}_{2.5}$ than the residential zone.

The lone appearance of $\mathrm{Cl}$ in Bonamoussadi indicates there is no local source in that locality. The high $\mathrm{Cl}$ concentration could either be from a sporadic source or blown in by the wind. PM concentrations here seem to be higher than for Bonamoussadi. $\mathrm{Ca}, \mathrm{Fe}, \mathrm{Zn}$ and $\mathrm{Pb}$ have highest concentrations as can be seen in Figure 3. Unlike in Bonamoussadi, $\mathrm{Ca}$ has peaks higher than the 0.3 line which can be explained by the presence of the cement industry in Bonaberi. $\mathrm{Cl}$ also presents concentrations higher than the other sites.

The relatively high concentration of $\mathrm{Pb}$ especially in Bonaberi can be accounted for by the presence of fuel from unofficial markets (locally known as "fungeh"). Leaded paint is also being scrapped from walls and spread in both old and new construction sites and also at the shipyard (eye witness account). Chronic exposure to low concentrations of $\mathrm{Pb}$ is very dangerous and can lead to reduction of intelligence, increased blood pressure and a range of behavioral and developmental effects (WHO 2005).

The results show a large variation in sample mass, $\mathrm{BC}$ concentration as well as in the concentrations of the analyzed elements. A look at the individual samples from the different sites (Figure 4) signifies that the variation of the different constituents does not show the same pattern. This adds to the picture of different sources for different pollutants and to the influence of meteorology on PM concentration. The different patterns are as shown in Figure 4(a-c).

Figure 4a. Individual Element Pattern for Elements Found in $P M_{2.5}$ in Bonamoussadi

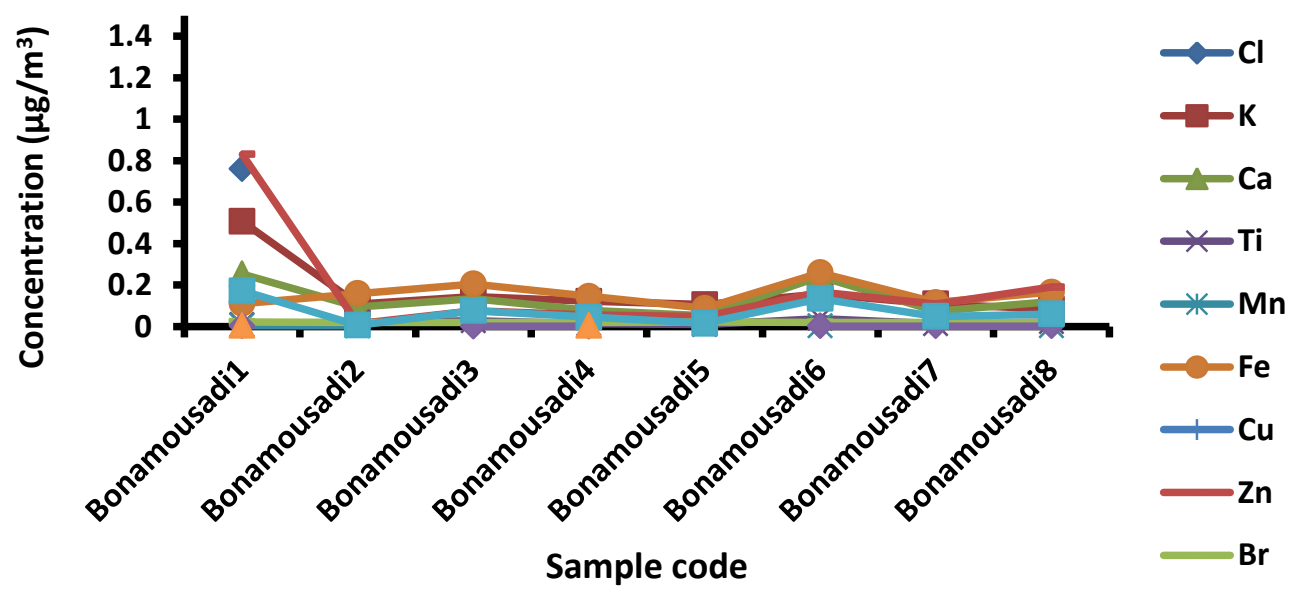


Figure 4b. Individual Element Pattern for Elements Found in PM 2.5 in Bonaberi

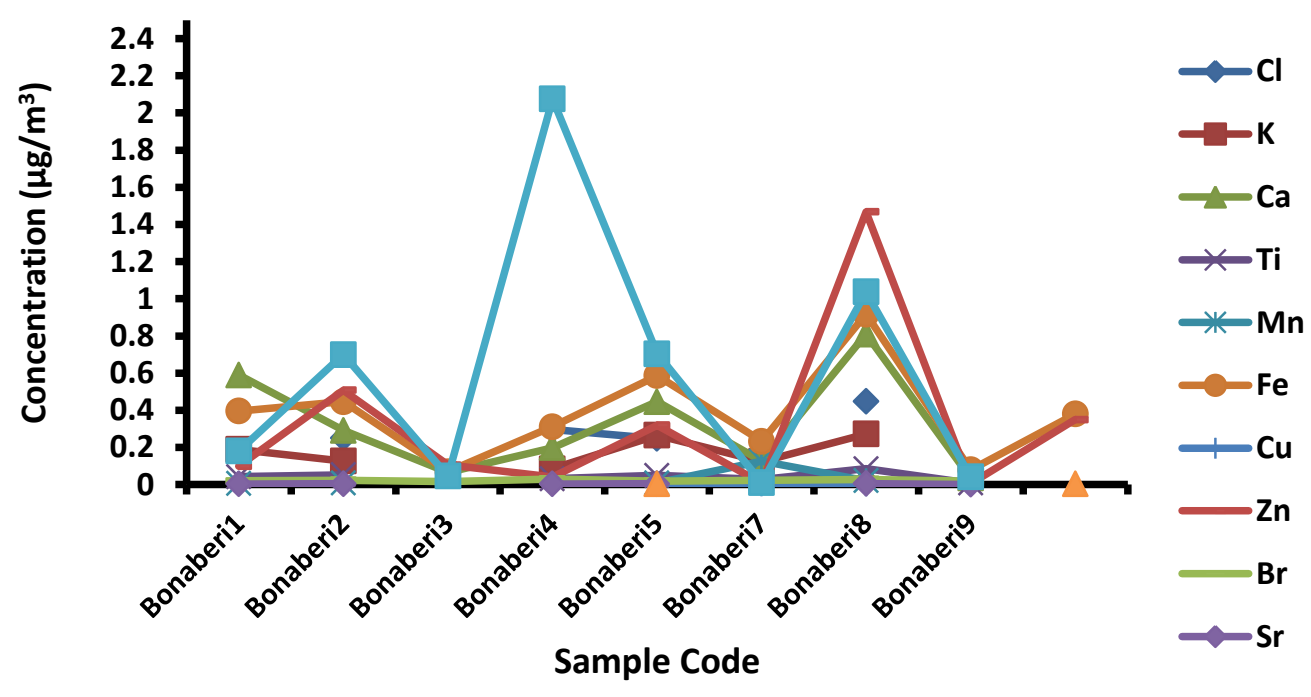

Figure 4c. Individual Element Pattern for Elements Found in PM 2.5 in Bassa

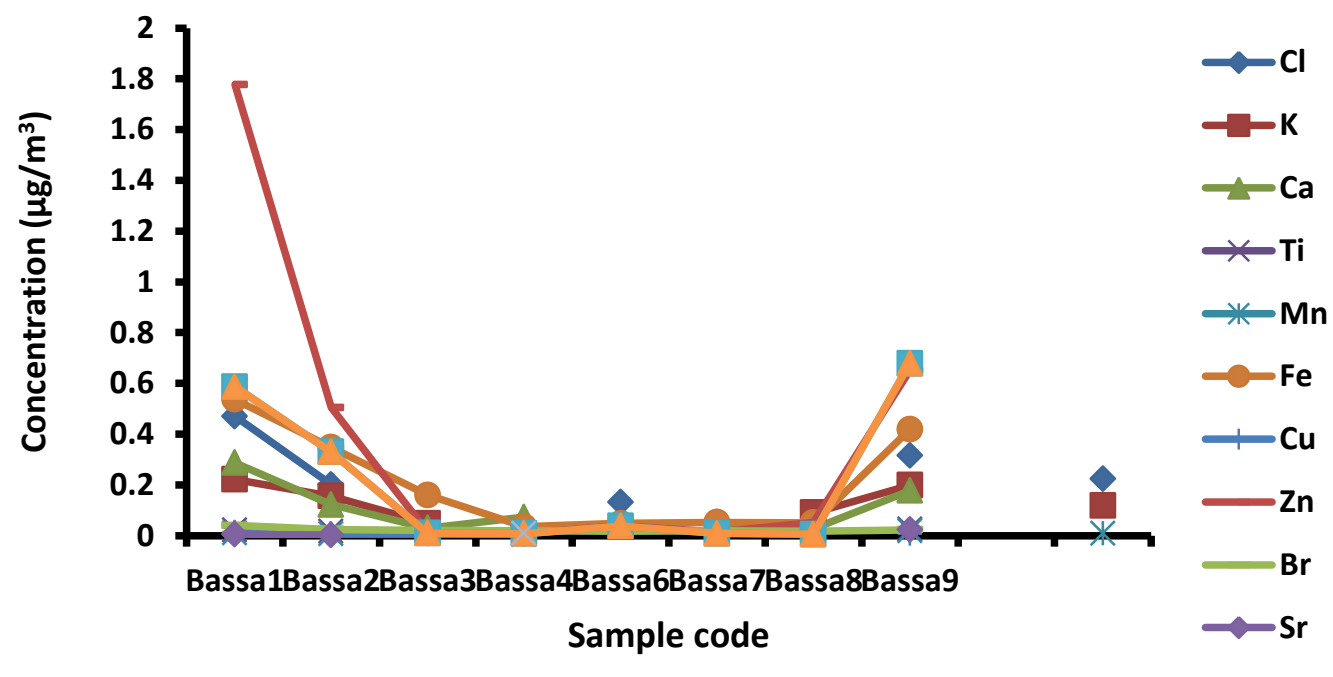

Black Carbon (BC)

Very high concentrations of $\mathrm{BC}$ are recorded for Bonaberi, high concentrations for Bonamoussadi and averagely high concentrations for Bassa. The mean concentration of Bonaberi, $3.17 \pm 2.376 \mu \mathrm{g} / \mathrm{m} 3$ as opposed to $1.42 \pm 0.459 \mu \mathrm{g} / \mathrm{m} 3$ for Bonamoussadi and $1.10 \pm 1.566 \mu \mathrm{g} / \mathrm{m} 3$ for Bassa is relatively very high (there is high use of fuel wood for household and commercial purposes in the area hence the high BC concentration for Bonamoussadi). The sampling site for Bonaberi is the gateway to and away from the Wouri Bridge hence very dense traffic for most parts of the day hence emissions from vehicle exhaust can explain the high BC concentration. The industrial zone also has very high dependence on fossil fuel for energy production. Bonamoussadi concentrations can be due to the burning of biomass for domestic purposes while vehicle emissions cannot be ignored. Traffic also accounts for that of the Bassa area which is a gateway from Douala to 
Yaoundé with high traffic at Ndokotti Market. Open burning and the high dependence on fuel wood and charcoal burning for domestic and commercial purposes significantly contribute the high $\mathrm{BC}$ concentrations for all the areas.

\section{Factor Analysis}

Three components were extracted by the analysis explaining a total of $76.8 \%$ variance for the whole data set as shown in Table 4. The first component is characterized by high loadings of $\mathrm{Fe}, \mathrm{K}, \mathrm{Zn}$, and moderately high loadings for $\mathrm{Cu}$, $\mathrm{Cl}, \mathrm{Sr}, \mathrm{Br}$, Ti, and $\mathrm{Ca}$. This component accounts for $50.5 \%$ of the total variance obtained. The component could be interpreted as a combination of geological (soil/crust) origin and combustion aerosols. There is a combination of high and moderately high loadings for elements which are derived from these sources. $\mathrm{K}$ and $\mathrm{Fe}$ for example have high loading and indicate soil originated aerosols, Ti and Ca have moderately high loadings and indicate soil originated aerosols while $\mathrm{Zn}$ with High loading indicate industrial activity (Boman et al. 2009a) especially metallurgical activities (Heal et al. 2012). The moderately high $\mathrm{Cl}$ and $\mathrm{Br}$ loadings also indicate industrial combustion. $\mathrm{Zn}$ and $\mathrm{Fe}$ could also be emitted from lubricating oil additives (used in two-stroke engine where engine oil is mixed with fuel), combustion of impure fuel, vehicle engine and brake tire wear.

Table 4. Component Matrix for Source Apportionment for Elements in Air Samples from Douala

\begin{tabular}{|l|c|c|c|}
\hline \multirow{2}{*}{ Elements } & \multicolumn{3}{|c|}{ Components } \\
\cline { 2 - 4 } & 1 & 2 & 3 \\
\hline $\mathrm{Cl}$ & 0.754 & -0.021 & -0.518 \\
\hline $\mathrm{K}$ & 0.882 & 0.367 & -0.130 \\
\hline $\mathrm{Ca}$ & 0.668 & 0.538 & 0.141 \\
\hline $\mathrm{Ti}$ & 0.721 & 0.050 & 0.517 \\
\hline $\mathrm{Mn}$ & 0.345 & 0.748 & 0.289 \\
\hline $\mathrm{Fe}$ & 0.946 & -0.207 & -0.063 \\
\hline $\mathrm{Cu}$ & 0.779 & 0.147 & -0.191 \\
\hline $\mathrm{Zn}$ & 0.818 & -0.158 & -0.150 \\
\hline $\mathrm{Br}$ & 0.727 & -0.357 & 0.168 \\
\hline $\mathrm{Sr}$ & 0.753 & -0.242 & -0.358 \\
\hline $\mathrm{Pb}$ & 0.394 & -0.730 & 0.394 \\
\hline $\mathrm{BC}$ & 0.450 & -0.049 & 0.581 \\
\hline
\end{tabular}

The first component has high loading for all detected elements but for $\mathrm{Mn}, \mathrm{Pb}$ and BC. Zn compounds are extensively employed as lubricants, antioxidants and as detergent/dispersant improvers for lubricating oils (Begum et al. 2007). The high and moderately high loadings are of more mixed character, possibly representing both soil and combustion origin. To confirm this mixed character, $\mathrm{Fe}$, $\mathrm{K}$, and $\mathrm{Ca}$ are characteristic to road dust attributed to diesel vehicle emissions. The industrial and petrochemical waste managing companies that incinerate most 
of these wastes could also be a significant source for these elements in the atmosphere.

The second component is characterized by moderate loading from $\mathrm{Mn}$, and this component accounts for $15.0 \%$ of the total variance obtained. Moderate loadings of Mn bear sign of aerosol from the metallurgical industry (Heal et al. 2012). This could be confirmed by the moderate loading of $\mathrm{Ca}$ in this component. Other activities generating Mn include vehicle engine, brake and tyre wear, and during combustion of impure fuel (particularly coal), and fuel and lubricating oil additives (Heal et al. 2012). Nonetheless, $\mathrm{Mn}$ and $\mathrm{Ca}$ are typical mineral elements and consequently, this factor could be associated with the crustal fraction of $\mathrm{PM}_{2.5}$ (Heal et al. 2005). The presence of these elements in $\mathrm{PM}_{2.5}$ could mainly be a result of local and regional dust re-suspension by wind, convection and other natural processes. However, if the emissions from incomplete and complete combustion of biomass have different sources, this could explain the appearance in two different components in the analysis.

The third component had moderate loading for $\mathrm{BC}$ accounting for $11.4 \%$ of the obtained variance. $\mathrm{BC}$ is a good marker for combustion - derived component of airborne particles. It is also a good marker for traffic-related PM pollution (Heal et al. 2012).

PCA for individual sampling sites showed same results as above implying that the individual sites have similar sources of particulate pollution.

$\mathrm{Ni}$ which was not included in the PCA due to its being below detection limits for most samples mainly comes from dust and re-suspended soil particles. It is also a tracer for the combustion of heavy fuel oil (Boman et al. 2010).

\section{Influence of Meteorology on PM Concentration}

Diurnal temperatures varied between $23^{\circ} \mathrm{C}$ and $31^{\circ} \mathrm{C}$ and relative humidity between 81 and $95 \%$. Winds in Douala were westerly, showing a diurnal pattern with gusts of up to $10 \mathrm{~m} / \mathrm{s}$ during daytime, while evenings and nights were generally calmer with very stable atmospheric conditions.

Scattered plots showing variation of meteorological variables with the elemental concentration for the sampling period are given in Figure 5.

Trends for the plot for temperature against mass concentration (A) show that as temperature increases in Bonaberi, the mass concentration reduces while mass concentration increases with increase in temperature for both Bonamoussadi and Bassa. These variations can be explained by the chemical species present in the $\mathrm{PM}_{2.5}$. The mass concentration reduction with increasing temperature for Bonaberi could be explained using the species present in the $\mathrm{PM}_{2.5}$. This trend may indicate the dominance of nitrates in this area since nitrates are semi-volatile. It could also indicate the dominance of primary particulates in this region (Seinfeld and Pandis 2007).

For Bonamoussadi and Bassa, mass concentration increases with increasing temperature indicating the probable presence of sulphates and dust. According to Seinfeld and Pandis (2007), the oxidation of $\mathrm{SO}_{2}$ to $\mathrm{SO}_{4}{ }^{2-}$ is temperature dependent and increases as temperature increases thus increasing the aerosol concentration. This also indicates that these two areas are dominated by secondary 
particulates. From literature, one of the precursor gases for the formation of secondary particulates is $\mathrm{SO}_{2}$ thus confirming the above assertion. On another hand, these variations can be explained by wind speeds and direction. The wind blows away from Bonaberi hence transporting away a bulk of the mass of particles with it, whereas for Bonamoussadi and Bassa, the wind blows to their direction bringing in more particles from the upwind. This confirms the theories of Brook et al. (2004), Dawson et al. (2007) and Tai et al. (2010).

Figure 5. Variation of PM Mass Concentration with Meteorological Parameters: (A) with Temperature, (B) with Rainfall, (C) with Wind Speed and (D) with Relative Humidity

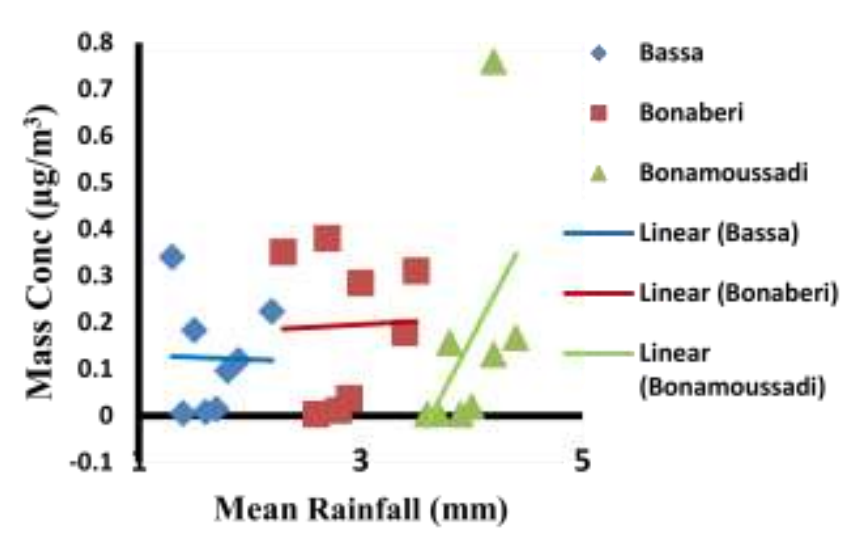

(A)

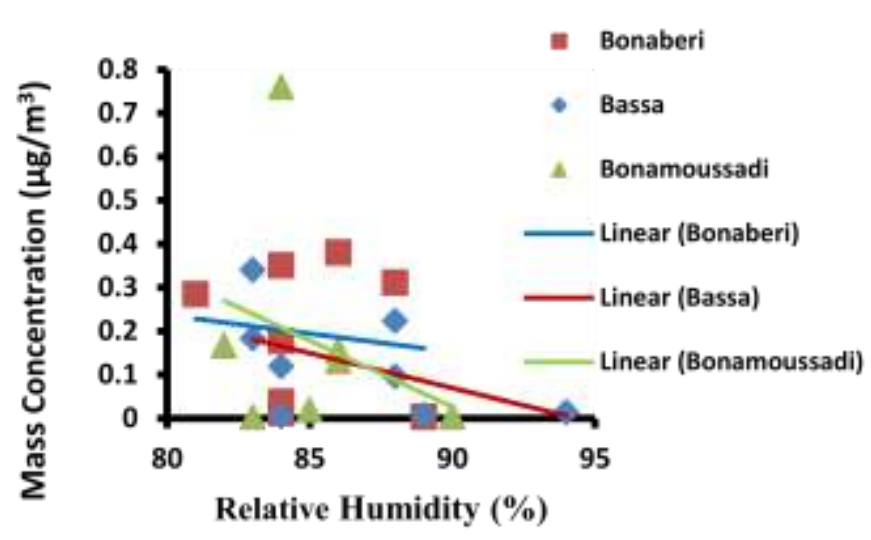

(C)

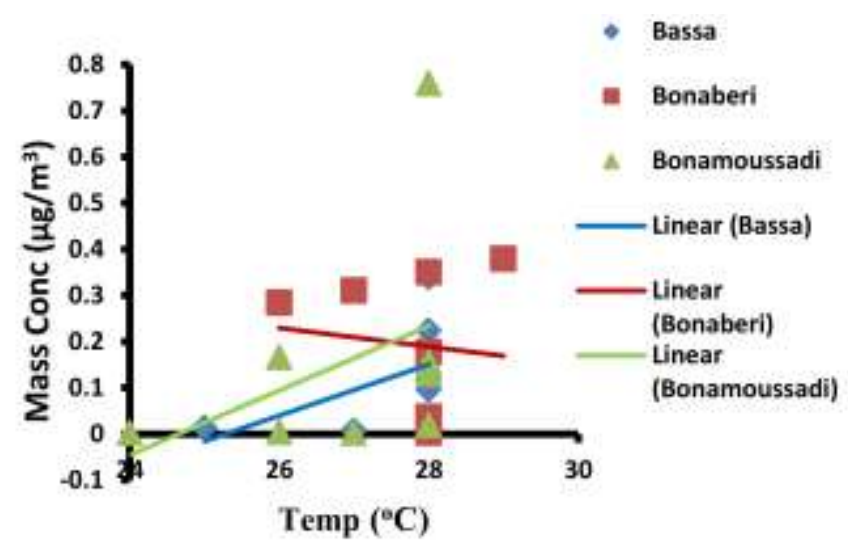

(B)

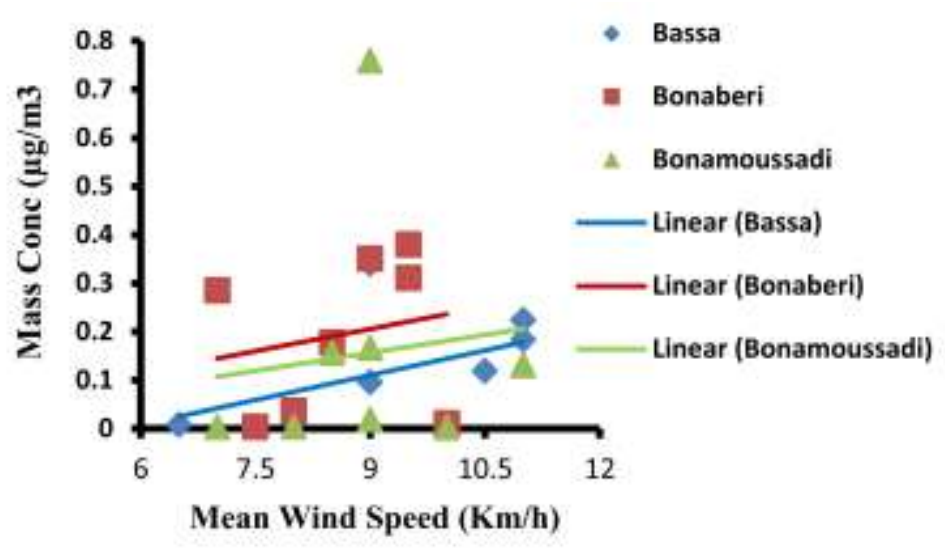

(D) 
Mass concentration of $\mathrm{PM}_{2.5}$ shows a slight decrease with increasing rainfall for Bassa. A slight increase is noticed for Bonaberi and a sharp increase for Bonamoussadi. This can be explained by the nature of rainfall which is predominantly thunderstorms. Depending on the strength of the wind during the storm, the process of wet deposition can be counteracted and the particles blown away in the wind faster than they are deposited or washed out by the rain. In this case, the particles are blown downwind and mass concentration can then increase in the downwind area with increasing rainfall. This confirms Dawson et al. (2007)'s conclusion that changes in precipitation in upwind areas affect $\mathrm{PM}_{2.5}$ concentrations in downwind areas and also explains the slight increase in PM mass concentration in Bonaberi as rainfall increases. The degree of change could be affected by the aerosol concentration of the upwind area.

PM mass concentration increases with increasing wind speed increases in all the locations contradicting the theories of Dawson et al. (2007) and Tai et al. (2010) which states that if the air is calm and pollutants cannot disperse then the concentration of these pollutants will build up. Conversely, if a strong, turbulent wind is blowing any pollution generated will be rapidly dispersed into the atmosphere resulting in lower pollutant concentrations in the air. This contradicting behaviour could be explained by the thunderstorm effect. However, it should be noted that the month of November which should be dry recorded quite some rainfall which could affect the behaviour of aerosols. In the dry season, there is the general tendency of particles to build up. And if suddenly strong winds and heavy rainfall come to play, patterns could be altered.

$\mathrm{PM}_{2.5}$ mass concentration generally decreases as relative humidity increases. According to Dawson et al. (2007) this trend can be explained by the different species in the $\mathrm{PM}_{2.5}$. Nitrates are semi-volatile thus, when relative humidity and temperature increase, they are taken out of the atmosphere by volatilisation hence reducing the mass concentration of $\mathrm{PM}_{2.5}$. This trend could be an indication that the $\mathrm{PM}_{2.5}$ in these areas is dominated by primary particulates. Tsigaridis and Kanakidou (2007) states that nitrates shift from particle phase to gas phase as temperature and relative humidity increase.

Comparing the average elemental concentrations in this study with selected studies from some African and European cities (Table 5), it can be seen that the concentrations of $\mathrm{Ca}, \mathrm{Ti}, \mathrm{Mn}$, and $\mathrm{Fe}$ are much higher in Ouagadougou than in Douala, and lower for the other regions than for these two cities.

In the comparison, the concentrations of $\mathrm{Br}$ and $\mathrm{Pb}$ are relatively low for all the other areas indicating a low influence of leaded fuel. For this study $\mathrm{Pb}$ is present in all the samples and in relatively high concentrations (Mean value of 292 $\mathrm{ng} / \mathrm{m}^{3}$ ) indicating the influence of leaded fuel and leaded paints. $\mathrm{Zn}$ also presents higher concentrations in this study than for the others. Apart from Ouagadougou, elemental concentrations are higher for this study than for the other studies. 
Table 5. Summary of Selected Elemental Concentrations in Fine Aerosol Particles from Different Measurements in Cities in Africa and Europe

\begin{tabular}{|l|c|c|c|c|c|}
\hline Dataset & This study & $\begin{array}{c}\text { Boman et al. } \\
2009 \mathrm{~b}\end{array}$ & $\begin{array}{c}\text { Gatari et al. } \\
2006\end{array}$ & $\begin{array}{c}\text { Heal et al. } \\
2005\end{array}$ & $\begin{array}{c}\text { Rodriguez } \\
\text { et al. 2004 }\end{array}$ \\
\hline Location & $\begin{array}{c}\text { Douala, } \\
\text { Cameroon }\end{array}$ & $\begin{array}{c}\text { Ouagadougou, } \\
\text { Burkina Faso }\end{array}$ & $\begin{array}{c}\text { Nairobi, } \\
\text { Kenya }\end{array}$ & Edinburg, UK & $\begin{array}{c}\text { Barcelona, } \\
\text { Spain }\end{array}$ \\
\hline Year & 2012 & 2007 & 2001 & $1999-2000$ & $1999-2000$ \\
\hline $\begin{array}{l}\text { Particle } \\
\text { size } \\
\text { range }\end{array}$ & $\mathrm{d}_{\mathrm{a}}<2.5 \mu \mathrm{m}$ & $\mathrm{d}_{\mathrm{a}}<2.5 \mu \mathrm{m}$ & $\mathrm{d}_{\mathrm{a}}<2.5 \mu \mathrm{m}$ & $\mathrm{d}_{\mathrm{a}}<2.5 \mu \mathrm{m}$ & $\mathrm{d}_{\mathrm{a}}<2.5 \mu \mathrm{m}$ \\
\hline $\mathrm{Cl}$ & 347 & 900 & $<\mathrm{DL}$ & & \\
\hline $\mathrm{K}$ & 167 & 290 & 730 & & 229 \\
\hline $\mathrm{Ca}$ & 190 & 690 & 70 & & 516 \\
\hline $\mathrm{Ti}$ & 29 & 240 & 8.7 & 0.4 & 16 \\
\hline $\mathrm{Mn}$ & 17 & 61 & 12 & 0.7 & 14 \\
\hline $\mathrm{Fe}$ & 248 & 3000 & 130 & 27.6 & 258 \\
\hline $\mathrm{Zn}$ & 296 & 41 & 100 & 7.5 & 162 \\
\hline $\mathrm{Br}$ & 22 & 8.7 & 36 & & 120 \\
\hline $\mathrm{Pb}$ & 292 & 11 & 76 & 11.36 & 1 . \\
\hline
\end{tabular}

\section{Conclusions}

$\mathrm{PM}_{2.5}$ for the city of Douala was collected over a 24-hour sampling period and analysed for mass, mass concentration and elemental composition. The cumulative mass concentration of $252 \pm 130.8 \mu \mathrm{g} / \mathrm{m}^{3}$ which is critically higher than the WHO standard of $25 \mu \mathrm{g} / \mathrm{m}^{3}$ was recorded. $\mathrm{Cl}, \mathrm{K}, \mathrm{Ca}, \mathrm{Ti}, \mathrm{Mn}, \mathrm{Fe}, \mathrm{Ni}, \mathrm{Cu}, \mathrm{Zn}, \mathrm{Br}, \mathrm{Sr}$, and $\mathrm{Pb}$ were identified in the $\mathrm{PM}$ collected. The high concentration of $\mathrm{Pb}$ indicated the possible use of leaded fuels and/or paints in the vicinity. The industrial zones exhibited higher PM concentrations than the residential areas. Meteorological parameters greatly influenced the PM concentration. However, the "thunderstorm effect" counteracted the normal variation of $\mathrm{PM}_{2.5}$ with wind speed and precipitation.

Diurnal patterns in concentrations suggested a common PM source. From PCA it was concluded that anthropogenic activities like traffic, biomass burning and industrial activities were the major PM sources. Old fleet and poorly maintained vehicles exacerbate the situation. Despite the high emission from these sources, natural sources such as sea spray and windblown dust significantly contribute to the PM load of this city.

Conclusively, the results presented in this study indicate that the majority of the Douala inhabitants are exposed to high air pollution levels in their everyday life. 


\section{Recommendations}

Given the high values of both elemental and PM concentrations in Douala, the following actions to reduce particulate matter and black carbon emissions are recommended:

- There should be very regular vehicle emissions tests, retirement, or retrofitting (e.g. adding particulate traps, including penalties for failing to meet air quality emissions standards, and heightened penalties for on-the-road "super-emitting" vehicles);

- The sale of certain fuels should be banned or strictly regulated. The use of cleaner fuels encouraged.

- The installation of a shore-based power/electrification of ships at port, regulating idling at terminals, and mandating fuel standards for ships seeking to dock at the Douala port.

- Banning or regulating slash-and-burn clearing of forests and burning of agricultural waste

- Biomas burning in urban and non-urban areas should be regulated and/or limited.

- Permits should be issued to operate industrial, and power generating, facilities, and periodic permit renewal and/or modification of equipment.

- Filtering technologies should be introduced together with high-temperature combustion for existing power generation plants. Annual emissions from such plants should also be regulated.

For $\mathrm{BC}$ it is necessary to focus on primary PM emission abatement measures such as:

- End-of-pipe technologies, i.e., diesel particle filters for road and off-road vehicles or machinery.

- Technologies allowing the reduction of emissions from medium- and small-scale combustion facilities, including domestic stoves (e.g., pellet stoves and boilers; product standards).

- Better implementation of the ban of open field burning of agricultural waste; such a ban has already been introduced in many EU Member States.

\section{Acknowledgments}

Our sincere thanks to the University of Gothenburg, Sweden for assisting in and providing equipment that was used for sample analysis. 


\section{References}

Adams K, Greenbaum DS, Shaikh R, van Erp AM, Russell AG (2015) Particulate matter components, sources, and health: systematic approaches to testing effects. Journal of the Air \& Waste Management Association 65(5): 544-558.

Agrawal M, Singh B, Rajput M, Marshall F, Bell JNB (2003) Effect of air pollution on peri-urban agriculture: a case study. Environmental Pollution 126(3): 323-329.

Amodio M, Andriani E, Cafagna I, Caselli M, Daresta BE, de Gennaro G et al. (2010) A statistical investigation about sources of PM in South Italy. Atmospheric Research 98(2-4): 207-218.

Amodio M, Andriani E, de Gennaro G, Di Gilio A, Ielpo P, Placentino M et al. (2013) How a steel plant affects air quality of a nearby urban area: a study on metals and $\mathrm{PAH}$ concentrations. Aerosol and Air Quality Research 13(2): 497-508.

Ariundelger A, Sonomdagva C, Yutaka M (2020) Mobile measurement of PM2.5 based on an individual in Ulaanbaatar city. International Journal of Environmental Research and Public Health 17(8): 2701.

Begum AB, Swapan KB, Hopke PK (2007) Source apportionment of air particulate matter by chemical mass balance $(\mathrm{CMB})$ and comparison with positive matrix factorization (PMF) model. Aerosol and Air Quality Research 7(4): 446-468.

Bell ML, Ebisu K, Peng RD, Dominici F (2009) Adverse health effects of particulate air pollution: modification by air pollution. Epidemiology 20(5): 682-686.

Boman J, Gatari MJ, Janhäll S, Shannigrahi AS, Wagner A (2009a) Elemental content of $\mathrm{PM}_{2.5}$ aerosol particles collected in Göteborg during the Göte-2005 campaign in February 2005. Atmospheric Chemistry and Physics 9(Apr): 2597-2606.

Boman J, Lindén J, Thorsson S, Holmer B, Eliasson I (2009b) A tentative study of urban and suburban fine particles $\left(\mathrm{PM}_{2.5}\right.$ collected in Ouagadougou, Burkina Faso. X-Ray Spectrometry 38(4): 354-362.

Boman J, Wagner A, Michael J, Gatari M (2010) Trace elements in $\mathrm{PM}_{2.5}$ in Gothenburg, Sweden. Spectrochimica Acta Part B 65(6): 478-482.

Brook RD, Franklin B, Cascio W, Hong Y, Howard G, Lipsett M et al. (2004) Air pollution and cardiovascular disease: a statement for healthcare professionals from the expert panel on population and prevention science of the American heart association. Circulation 109(21): 2655-2671.

Brook RD, Rajagopalan S, Pope C, Brook RJ, Bhatnagar A, Diez-Roux AV et al. (2010) Particulate matter air pollution and cardiovascular disease; an update to the scientific statement from the American heart association. Circulation 121(21): 2331-2378.

Cao Q, Rui G, Liang Y (2018) Study on PM2.5 pollution and the mortality due to lung cancer in China based on geographic weighted regression model. BMC Public Health 18(1): 925.

Chow JC, Watson JG (1998) Guideline on speciated particulate monitoring. Draft Report prepared by U.S. EPA Research Triangle Park, NC 27711 by the Desert Research Institute, Reno, NV89506.

Dawson JP, Adams PJ, Pandis SN (2007) Sensitivity of $\mathrm{PM}_{2.5}$ to Climate in the Eastern US: a modelling case study. Atmospheric Chemistry and Physics 7(16): 4295-4309.

Din N, Saenger P, Jules PR, Siegried DD, Basco F (2008) Logging activities in Mangrove forests: a case study of Douala Cameroon. African Journal of Environmental Science and Technology 2(2): 22-30.

Djuikom E, Louis B, Nola M (2011) Assessment of the quality of water in Wells at Bépanda Quarter, Douala-Cameroon, by use of the indicator bacteria of faecal contamination. Journal of Applied Biosciences 37(Jan): 2434-2440. 
Donaldson D, Hadoke PW, Boon NA, MacNee W, Cassee FR, Sandström T et al. (2009) Adverse cardiovascular effects of air pollution. Nature Clinical Practice Cardiovascular Medicine 6(1): 36-44.

Fonge BA, Tening AS, Egbe AE, Awo EM, Focho DA, Oben PM et al. (2011) Fish (Arius heudelotii Valenciennes, 1840) as bio-indicator of heavy metals in Douala Estuary of Cameroon. African Journal of Biotechnology 10(73): 16581-16588.

Forster P, Ramaswamy V, Artaxo P, Berntsen T, Betts R, Fahey DW, et al. (2007) Changes in atmospheric constituents and in radiative forcing. Contribution of working group I to the fourth assessment report of the intergovernmental panel on climate change. In SD Solomon, MR Qin, Z Manning, M Chen, KB Marquis, M Averyt et al. (eds.), Climate Change 2007: The Physical Science Basis, 131-217. Cambridge, United Kingdom: Cambridge University Press.

Fortoul TI, Rojas-Lemus M, Rodriguez-Lara V, Cano-Gutierrez G, Gonzalez-Villalva A, Ustarroz-Cano $\mathrm{M}$ et al. (2012) Air pollution and its effects in the respiratory system. Mexico: Departamento de Biologia Celulary Tisular, Facultad de Medicina Universidad Nacional Autonoma de Mexico (UNAM).

Gatari MJ, Boman J, Wagner A, Janhall S, and Isakson J (2006) Assessment of inorganic content of $\mathrm{PM}_{2.5}$ particles sampled in a rural area north-east of Hanoi, Vietnam, Science of the Total Environment 368(675).

Goldoni M, Caglieri A, Poli D, Vettori M, Corradi M, Apostoli P et al. (2006) Determination of hexavalent chromium in exhaled breath condensate and environmental air among chrome plating workers. Analytica Chimica Acta 562(2): 229-235.

Götschi T, Hazenkamp-von Arx ME, Heinrich J, Bono R, Burney P, Forsberg B et al. (2005) Elemental composition and reflectance of ambient fine particles at 21 European locations. Atmospheric Environment 39(32): 5947-5958.

Heal MR, Hibbs LR, Agius RM, Beverland IJ (2005) Total and water soluble trace metal content of urban background $\mathrm{PM}_{10}, \mathrm{PM}_{2.5}$ and black smoke in Edinburgh, UK. Atmospheric Environment 39(8): 1417-1430.

Heal MR, Prashant K, Roy MH (2012) Particles, air quality, policy and health. Chemical Society Reviews 41(19): 6606-6630.

Jeong CH, Evans GJ, Dann T, Graham M, Herod D, Dabek-Zlotorzynska E et al. (2008) Influence of biomass burning on wintertime fine particulate matter: source contribution at a valley site in rural British Columbia. Atmospheric Environment 42(16): 3684-3699.

JV (2013) More than 80000 used vehicles imported last year. Business in Cameroon.

Kaonga B, Ebenso E (2011) An evaluation of atmospheric aerosols in Kanana, Klerksdorp gold mining town, in the North-West province of South Africa. In AM Nicolás (ed.), Air Quality Monitoring, Assessment and Management. NC-SA 3.0.

Katsouyanni K, Samet JM, Anderson HR, Atkinson R, Le Tertre A, Medina S et al. (2009) Air pollution and health: a European and North American approach (APHENA). Research Report 142. Boston, MA, USA: Health Effects Institute.

Kawata K, Yokoo H, Shimazaki R, Okabe S (2007) Classification of heavy metal toxicity by human DNA microarray analysis. Environmental Science and Technology 41(10): 3769-3774.

Kelly FJ, Fussell JC (2011) Air pollution and airway disease. Clinical and Experimental Allergy 41(8): 1059-1071.

Kemajou A, Bergossi O, Tamo TT, Diboma BS (2007) Is industrial development incompatible with constraints of industrial ecology in Cameroon? International Scientific Journal for Alternative Energy and Ecology 6(62). 
Kuan KL, Mark RM, Anoop SVS (2017) Air pollution and stroke. Journal of Stroke 20(1): 2-11.

Lecoeur À, Seigneur C, Terray L, Pagé C (2012) Influence of climate on PM2.5 concentrations over Europe: a meteorological analysis using a 9-year model simulation. Vienna, Austria: EGU General Assembly.

Li X, Feng YJ, Liang HY (2017) The impact of meteorological factors on PM2.5 variations in Hong Kong. In IOP Conference Series: Earth and Environmental Science 78: 012003.

Loxham M, Nieuwenhuijsen MJ (2019) Health effects of particulate matter air pollution in underground railway systems - A critical review of the evidence. Particle and Fibre Toxicology 16(1): 12.

Manisalidis I, Stavropoulou E, Stavropoulos A, Bezirtzoglou E (2020) Environmental and health impacts of air pollution: a review. Frontiers in Public Health 8(Feb): 14.

Moln’ar P, Johannesson S, Boman J, Barregård L, Sällsten G (2006) Personal exposures and indoor, residential outdoor, and urban background levels of fine particle trace elements in the general population. Journal of Environmental Monitoring 8(5): 543551.

Omidvarborna H, Ashok K, Dong-Shik K (2015) Recent studies on soot modeling for diesel combustion. Renewable and Sustainable Energy Reviews 48(Aug): 635-647.

Pinto Miranda Garcia JN, Borrega J, Coelho LMR (2018) Airborne PM impact on health, overview of variables, and key factors to decision making in air quality. In J Del Real Olvera (ed.), Air Pollution - Monitoring, Quantification and Removal of Gases and Particles. IntechOpen.

Querol X, Alastuey A, Rodriguez S, Plana F, Ruiz CR, Cots N et al. (2001) PM $_{10}$ and $\mathrm{PM}_{2.5}$ source apportionment in the Barcelona Metropolitan area, Catalonia, Spain. Atmospheric Environment 35(36): 6407-6419.

Querol X, Zhuang X, Alastuey A, Viana M, Wang Y, Lopez A et al. (2006) Speciation and sources of atmospheric aerosols in a highly industrialized emerging mega-city in Central China. Journal of Environmental Monitoring 8(10): 1049-1059.

Querol X, Minguillon MC, Alastuey A, Monfort E, Mantilla E, Sanz MJ et al. (2007) Impact of implementation of PM abatement technology on the ambient air levels of metals in a highly industrialized area. Atmospheric Environment 41(5): 1026-1040.

Rodriguez S, Querol X, Alastuey A, Viana M, Alarcon M, Mantilla E et al. (2004) Comparative $\mathrm{PM}_{10}-\mathrm{PM}_{2.5}$ source contribution study at rural urban and industrial sites during PM episodes in Eastern Spain. Science of the Total Environment 328(13): $95-113$.

Sánchez de la Campa AM, Sánchez -Rodas D, Alastuey A, Querol X, de la Rosa JD (2018) Air quality trends in an industrialised area of SW Spain. Journal of Cleaner Production 186(Jun): 465-474.

Schwarze PE, Oyreyik J, Lag M, Refsnes M, Nafstad P, Hetland RB et al. (2006) Particulate matter properties and health effects: consistency of epidemiological and toxicological studies. Human and Experimental Toxicology 25(10): 559-579.

Seinfeld JH, Pandis SN (2006) Atmospheric chemistry and physics; from air pollution to climate change. $2^{\text {nd }}$ Edition. Hoboken, NJ, USA: John Wiley \& Sons.

Siegfried DD, Obiang NE, Din N, Priso RJ, Victortaffouo, Fankem H ET AL. (2009) The Loranthaceae: an asses for the rise of the traditional pharmacopoeia in Cameroon. International Journal of Biological and Chemical Sciences 3(4): 746-754.

Tai APK, Mickley LJ, Jacob DJ (2010) Correlations between fine particulate matter $\left(\mathrm{PM}_{2.5}\right)$ and meteorological variables in the United States: implications for the sensitivity of $\mathrm{PM}_{2.5}$ to climate change. Atmospheric Environment 44(32): 3976-3984. 
Tai APK, Mickley LJ, Jacob DJ, Leibensperger EM, Zhang L, Fisher JA (2012) Meteorological modes of variability for fine particulate matter $\left(\mathrm{PM}_{2.5}\right)$ air quality in the United States: implications for $\mathrm{PM}_{2.5}$ sensitivity to climate change. Atmospheric Chemistry and Physics 12(6): 3131-3145.

Tiwari S, Chate DM, Pragya P, Kaushar A, Deewan SB (2012) Variations in mass of the PM10, $\mathrm{PM}_{2.5}$ and $\mathrm{PM}_{1}$ during the monsoon and the winter at New Delhi. Aerosol and Air Quality Research 12(1): 20-29.

Tsai SS, Goggins WB, Chiu HF, Yang CY (2003) Evidence for an association between air pollution and daily stroke admissions in Kaohsiung, Taiwan. Stroke 34(11): 26122616.

Tsigaridis K, Kanakidou M. (2007) Secondary organic aerosol importance in the future atmosphere. Atmospheric Environment 41(22): 4682-4692.

United Nations - UN (2018) Africa used vehicle report. In Proceedings for the African Clean Mobility Week.

Van Grieken RE, Markowicz AA (1993) Handbook of X-ray spectrometry - Methods and techniques. New York: Marcel Dekker.

Viana M, Querol X, Gotschi T, Alastuey A, Sunyer J, Forsberg B et al. (2007) Source apportionment of ambient $\mathrm{PM}_{2.5}$ at five Spanish centers of the European community respiratory health survey (ECRHS II). Atmospheric Environment 41(7): 1395-1406.

Wang X, Liu J, Che H, Ji F, Liu J (2018) Spatial and temporal evolution of natural and anthropogenic dust events over Northern China. Scientific Reports 8(Feb): 2141.

Webb PN, Pierre C (2018) Quantifying anthropogenic dust emissions. Earth's Future 6(2): 286-295.

Wei D, Gao JQ, Wang B, Ouyang F (2012) Statistical analysis of weather effects on $\mathrm{PM}_{2.5}$. Advanced Materials Research 610(Jan): 1033-1040.

World Health Organisation - WHO (2003) Health aspects of air pollution with particulate matter, ozone and nitrogen dioxide. Report on a WHO Working Group. Bonn, Germany: WHO.

World Health Organisation - WHO (2005) Effects of air pollution on children's health and development: a review of the evidence, E86575. Bonn, Germany: WHO.

World Health Organisation - WHO (2007) Health relevance of particulate matter from various sources. Report on a WHO Workshop. Bonn Germany: WHO.

Ya-Gao Q, Chen Y, Guo-Liu D, Jian-Zhang M (2019) Investigating the influence of meteorological factors on particulate matters: a case study based on path analysis. Energy and the Environment 31(3): 479-491.

Zhou ZH, Xie SF, L GH, Zhao Y, Zhang W (2020) Analysis and prediction of $\mathrm{PM}_{2.5}$ concentration in Guilin city. In The International Archives of the Photogrammetry, Remote Sensing and Spatial Information Sciences XLII-3/W10: 1081-1089. 
